\title{
Napawanie regeneracyjne narzędzi do kucia na gorąco kołnierzy z szyjką
}

\author{
Hardening tools for hot forging flanges with a neck
}

\section{Streszczenie}

Kucie kołnierzy stalowych z szyjką, gdzie temperatura odkuwki wynosi ok. $1150^{\circ} \mathrm{C}$ stawia niezwykle wysokie wymagania matrycom. Odporność na zużycie ścierne, zmęczenie cieplne, adhezyjne itp. są bardzo istotnymi parametrami mającymi wpływ na trwałość narzędzi kuźniczych. Azotowanie dyfuzyjne oraz powłoki CVD są często stosowane w celu zwiększenia trwałości narzędzi kuźniczych. Procesy te jednak nie znajdują zastosowania jako regeneracyjne metody zwiększania przydatności narzędzi do pracy. Z pomocą przychodzą technologie spawalnicze. Napawanie prewencyjne podobnie jak regeneracyjne mają duże zastosowanie w przemyśle kuźniczym [1 $\div 5]$.

Słowa kluczowe: napawanie; powłoki; modyfikacja powierzchni

\begin{abstract}
In the forging of steel flanges with neck, where the forging temperature is around $1150^{\circ} \mathrm{C}$, it places extremely high demands on the dies. Abrasive wear, thermal fatigue, adhesion, etc. are very important parameters affecting the durability of forging tools. Nitriding and CVD coatings are often used to make wear resistance better. These processes, however, are not intended to be used as regenerative methods for increasing the suitability of work tools. Welding technologies come with help. Preventive as well as regenerative repairs have great applicability in the forging industry.
\end{abstract}

Keywords: padwelding; coatings; surface modification

\section{Wprowadzenie}

Narzędzia kuźnicze wykonane ze stali narzędziowej do pracy na gorąco stosowane w procesach kucia matrycowego charakteryzują się stosunkowo niską trwałością, co z kolei w sposób znaczący wpływa na jakość i koszt wytwarzania odkuwek. Niedostateczna trwałość narzędzi kuźniczych spowodowana jest przede wszystkim warunkami panującymi w przemysłowych procesach kucia na gorąco, wynikającymi z jednoczesnego występowania wielu złożonych mechanizmów niszczących. Zagadnienie trwałości narzędzi kuźniczych stanowi wciąż trudny i nierozwiązany problem, zarówno pod względem naukowym, jak i przemysłowym $[1,3]$. Do najbardziej popularnych i chętnie stosowanych metod podnoszenia trwałości narzędzi należą: odpowiedni dobór materiału dla danego procesu lub operacji [1 $\div 3$, jego obróbka cieplna, cieplno-chemiczna, wytwarzanie powłok $[1,6]$ oraz optymalizacja kształtu i konstrukcji oprzyrządowania $[1,3,4]$. Ważny jest też odpowiedni dobór warunków technologicznych np.: związanych z określeniem temperatur, dobór środka chłodzącego i sposobu jego podawania, czy rozwiązań technologiczno-konstrukcyjnych, a także systemów pomiarowo-kontrolnych [4]. Jedną $z$ opracowywanych metod poza stosowaniem azotowania oraz powłok PVD jest stosowanie napawania na matryce kuźnicze do pracy na gorąco. Poniżej przedstawiono wynik z przeprowadzonych prób oraz wytyczne do opracowania procesu technologicznego nakładania powłok.

\section{Zakres badań}

Do badań wytypowano proces kucia na gorąco kołnierza z szyjką $\emptyset 100$. Proces ten realizowany jest w Kuźni Jawor na prasie korbowej z maksymalną siłą nacisku 2500 ton. Za materiał wsadowy służy wstępniak o kształcie prostopadłościanu uzyskany metodą odlewania ciągłego, który jest nagrzewany do temperatury $1150^{\circ} \mathrm{C}$ i następnie kształtowany w trzech operacjach - spęczania, matrycowania wstępnego oraz matrycowania wykańczającego. W analizowanym procesie spęczanie ma głównie za zadanie nadać odkuwce wstępne kształty, pozwalające na łatwiejsze wypełnienie wykroju matryc w kolejnych operacjach, a także usunięcie zgorzeliny. $\mathrm{Na}$ etapie matrycowania wstępnego produkt przyjmuje właściwy kształt, a kucie wykańczające odpowiada za jego kalibrację, głównie zmianę promieni zaokrągleń

Dr inż. Marcin Kaszuba, dr inż. Maciej Zwierzchowski, dr inż. Artur Lange - Politechnika Wrocławska.

Autor korespondencyjny/Corresponding author: artur.lange@pwr.edu.pl 
i niektórych wymiarów. W prowadzonych badaniach skoncentrowano się na drugiej operacji (kucie wstępne), która jest kluczową ze względu na jakość końcowego wyrobu. Dla narzędzi stosowanych w tej operacji obserwuje się również niską trwałość, która średnio wynosi ok. 10000 szt. odkuwek. Analizie poddano dolną matrycę stosowaną w drugiej operacji (rys.1).
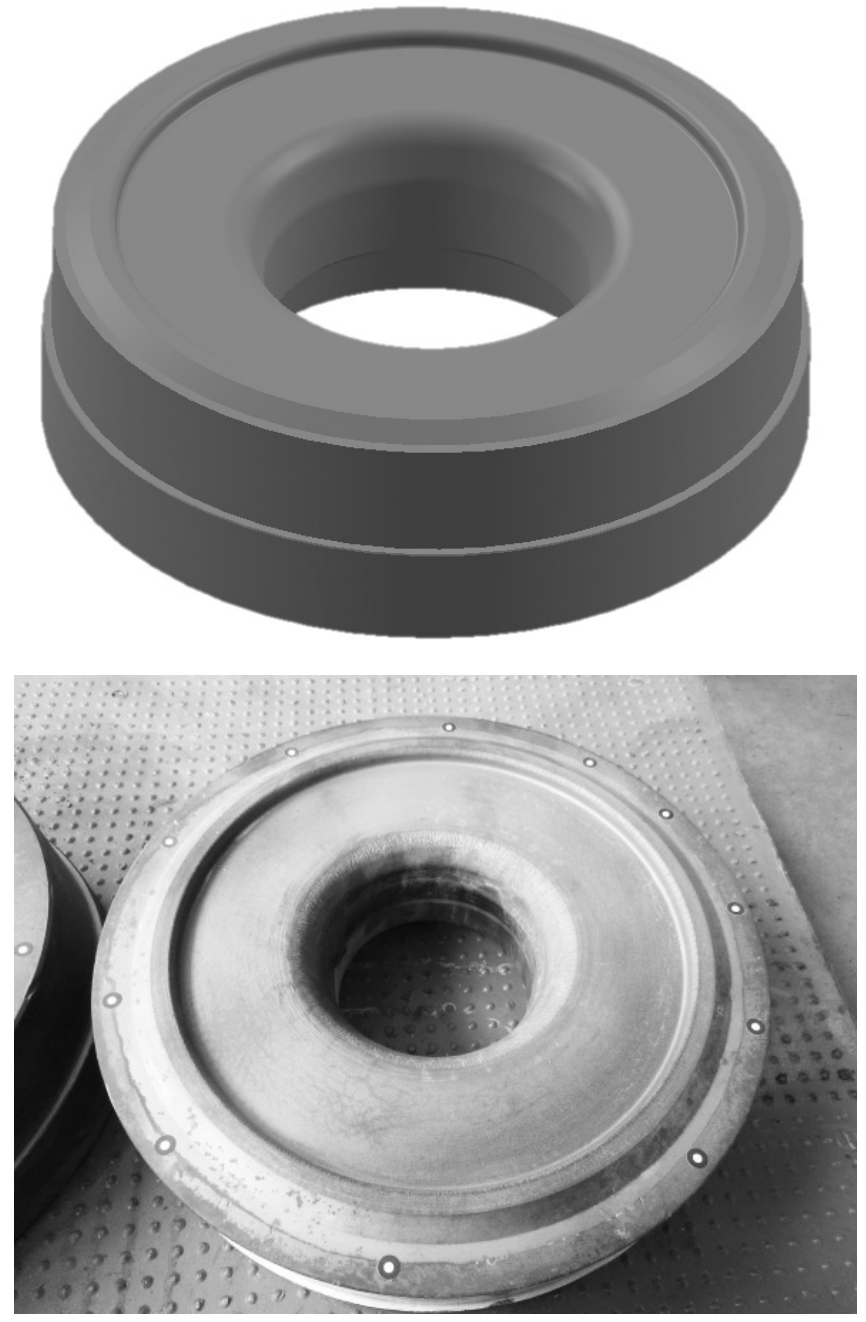

Rys. 1. Model oraz wygląd analizowanej dolnej matrycy wstępnej Fig. 1. Model and appearance of the analyzed lower pre-matrix

Matryca wykonana była ze stali narzędziowej do pracy na gorąco WCL (1.2343), po obróbce cieplnej (hartowanie $+2 x$ odpuszczanie) matryca ta została poddana azotowaniu na twardość $1100 \div 1200$ HV0,1, grubość warstwy azotowa-

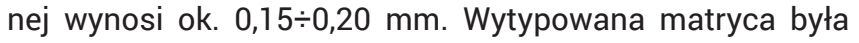
eksploatowana w warunkach produkcyjnych w Kuźni Jawor i odkuto przy jej użyciu ok. 12000 szt. po czym stwierdzono, że matryca jest zużyta. Następnie matryca ta przeszła kontrolę mającą na celu zakwalifikowanie jej do regeneracji przez napawanie.

\section{Proces wytwarzania powłok}

Napawanie przeprowadzono zgodnie z opracowaną do tego celu instrukcją technologiczną napawania. W pierwszej kolejności matryca została oczyszczona, następnie wykrój na całej powierzchni został obniżony przez toczenie o $1 \mathrm{~mm}$, natomiast w obszarze mostka (tam gdzie zużycie jest najbardziej intensywne) o $2 \mathrm{~mm}$. Wszystkie promienie w wykroju roboczym zostały przygotowane na minimum R6.
W przypadku wystąpienia pęknięcia w narożu wkładki powinno zostać wykonane łagodne wybranie o promieniu R6 na głębokość min. $3 \mathrm{~mm}$.

Tak przygotowana matryca została poddana napawaniu. Na rysunku 2 przedstawiono sposób układania ściegów podczas napawania w analizowanej matrycy.

Do napawania wykorzystano spoiwo o handlowej nazwie Welding Alloys - Robotool 46, w tablicy I przedstawiono skład chemiczny zastosowanego spoiwa. Parametry procesu napawania analizowanej matrycy przedstawiono w tablicy II.

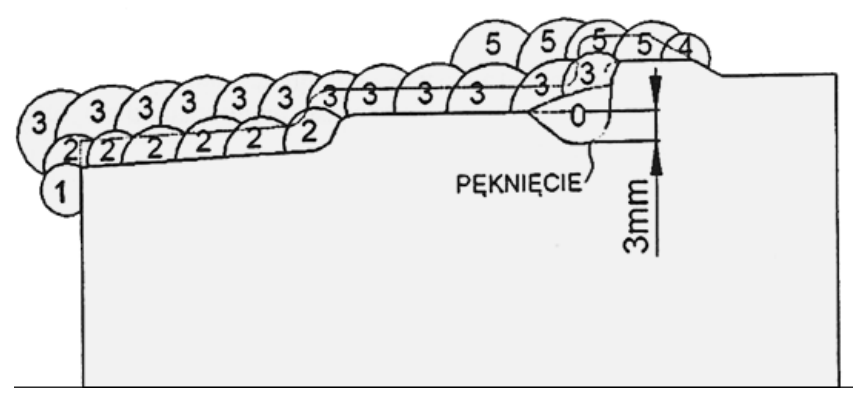

Rys. 2. Sposób układania ściegów przy napawaniu analizowanej matrycy

Fig. 2. Method of laying stitches when applying the analyzed matrix

Tablica I. Skład chemiczny spoiwa Robotool 46

Table I. Chemical composition of the Robotool 46 binder

\begin{tabular}{|c|c|c|c|c|c|c|}
\hline $\mathbf{C}$ & Mn & Si & Cr & Mo & Ti & Fe \\
\hline 0,20 & 0,90 & 0,50 & 5,10 & 3,80 & 0,25 & Rem. \\
\hline
\end{tabular}

Tablica II. Parametry realizowanego procesu napawania Table II. Parameters of the hardfacing process

\begin{tabular}{|c|c|}
\hline Proces spawania & $\begin{array}{c}138 \\
\text { (spawanie drutem proszkowym } \\
\text { z rdzeniem metalicznym) }\end{array}$ \\
\hline Wymiar spoiwa [mm] & 1,6 \\
\hline Natężenie prądu [A] & $\begin{array}{l}\text { Nr ściegu: } \\
1 \div 4-190 \\
2 \div n-285\end{array}$ \\
\hline Napięcie łuku [V] & $\begin{array}{l}\text { Nr ściegu: } \\
1 \div 4-22,6 \\
2 \div \mathrm{n}-31,5\end{array}$ \\
\hline Rodzaj biegunowości & $\mathrm{DC}+$ \\
\hline $\begin{array}{l}\text { Prędkość napawania [cm/ } \\
\text { min] }\end{array}$ & 30 \\
\hline Gaz osłonowy & ISO $14175-\mathrm{M} 14-\mathrm{ArCO}-5 / 2$ \\
\hline $\begin{array}{l}\text { Prędkość przepływu gazu } \\
\text { [I/min] }\end{array}$ & $14 \div 17$ \\
\hline $\begin{array}{l}\text { Długość wolnego wylotu } \\
\text { drutu [mm] }\end{array}$ & $12 \div 18$ \\
\hline $\begin{array}{l}\text { Kąt ustawienia uchwytu } \\
\text { spawalniczego }\end{array}$ & $\begin{array}{l}\text { Prostopadle do napawanej } \\
\text { powierzchni }\end{array}$ \\
\hline $\begin{array}{l}\text { Temperatura podgrzania } \\
\text { wstępnego }\left[{ }^{\circ} \mathrm{C}\right]\end{array}$ & $\sim 350$ \\
\hline $\begin{array}{c}\text { Temperatura } \\
\left.\text { międzyściegowa [ }{ }^{\circ} \mathrm{C}\right]\end{array}$ & $\sim 400$ \\
\hline
\end{tabular}


W przypadku wystąpienia pęknięcia na narożu matrycy (rys. 2) ścieg 0 wykonano przy użyciu spoiwa o handlowej nawie Castolin XHD 646, metodą 111 (elektroda otulona).

Analizowana matryca bezpośrednio po napawaniu została poddana wyżarzaniu odprężającemu w piecu w temperaturze $450{ }^{\circ} \mathrm{C}$ przez 4 godziny, następnie wolno chłodzona z piecem. Po tym zabiegu matrycę poddano mechanicznej obróbce wykańczającej przez toczenie zgodnie z rysunkiem technicznym.

Tak przygotowana matryca ponownie została oddana na produkcję i ponownie odkuto przy jej użyciu 13000 odkuwek. Po stwierdzeniu, że analizowana matryca jest zużyta, powtórzono całą powyżej opisaną procedurę regeneracji przez napawanie. Następnie matryca ponownie trafiła na produkcję, podczas której odkuto przy jej użyciu 10000 szt. odkuwek.

W badaniach analizowanej matrycy zastosowano następujące techniki badawcze:

- analize makroskopowa powierzchni roboczej matrycy:

- analizę wymiarów za pomocą skanowania powierzchni roboczych narzędzi

do określenia wartości zużycia w poszczególnych miejscach narzędzi użyto skanera laserowego zintegrowanego $z$ ramieniem pomiarowym ROMER Absolute ARM 7320si;

- pomiary mikrotwardości HV0,1

profile mikrotwardości Vickersa na przekroju poprzecznym w kierunku od powierzchni roboczej w głąb narzędzi wykonano zgodnie z wytycznymi normy PN-EN ISO 6507 -1:2007 - Pomiar twardości sposobem Vickersa: Metoda badań, przy sile obciążającej 0,98 N;

- mikroskopię optyczną

obserwacje mikroskopowe - badania struktury w próbkach wyciętych z narzędzi prowadzono za pomocą mikroskopu optycznego OLYMPUS GX 51. Badania wykonano na próbkach trawionych 3,5 procentowym alkoholowym roztworem kwasu azotowego (Nital);

- mikroskopię elektronową SEM

badania struktury próbek oraz powierzchni roboczych narzędzi wykonano za pomocą skaningowego mikroskopu elektronowego TESCAN VEGA 3.

\section{Analiza makroskopowa}

Na płaskiej powierzchni matrycy widoczne są duże obwodowe pęknięcia (rys. 3a) natomiast nie stwierdzono występowania siatki pęknięć cieplno-mechanicznych obserwowanych na innych matrycach stosowanych w tej operacji, które były poddawane azotowaniu. Na promieniu w środkowej części matrycy zaobserwowano charakterystyczne dla zużycia ściernego bruzdy (rys. 3b).

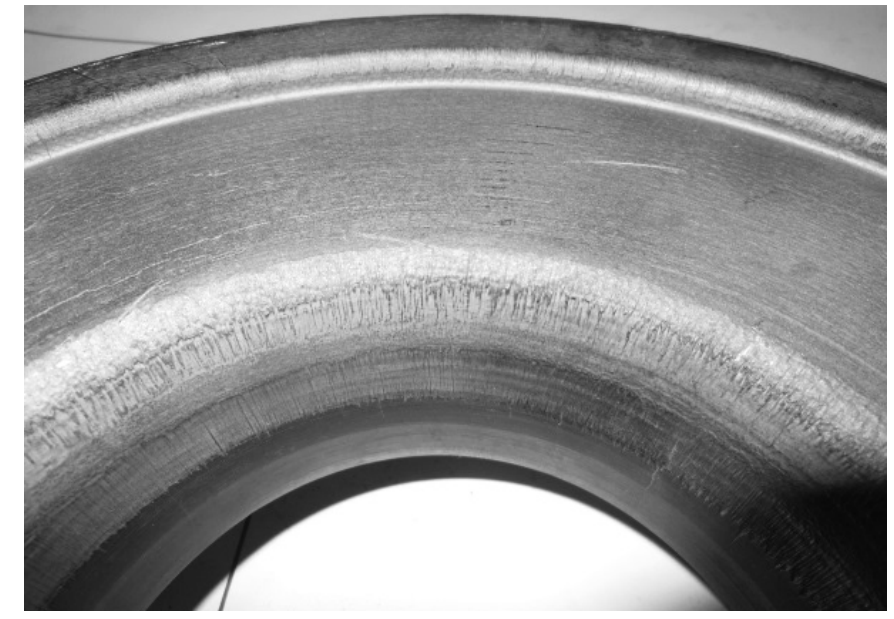

\section{Analiza wymiarowa}

Do określenia wartości zużycia w poszczególnych miejscach matrycy użyto skanera laserowego zintegrowanego z ramieniem pomiarowym ROMER Absolute ARM 7320si.

Dane zebrane ze skanowanej powierzchni roboczej analizowanej matrycy, zostały porównywane z kształtem pierwotnym narzędzi przed pracą. Referencyjnym modelem był model CAD. Wyniki w postaci kolorowych map z odchyłkami względem wymiaru nominalnego, jakim jest model CAD, przedstawiono na rysunkach 4 i 5 .

Na rysunkach 4 i 5, które przedstawiają porównanie zeskanowanych obrazów matrycy z modelem CAD po odkuciu 10000 odkuwek, nie zaobserwowano istotnego geometrycznego ubytku materiału. Największe zużycie można zaobserwować na promieniu w środkowej części oraz na mostku matrycy.
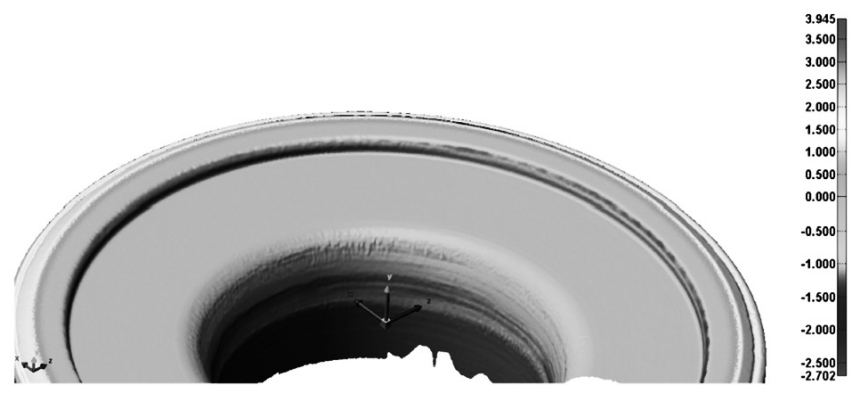

Rys. 4. Porównanie zeskanowanych obrazów matrycy z modelem CAD po odkuciu $10000 \mathrm{szt}$

Fig. 4. Comparison of scanned matrix images with CAD model after 10000 pieces

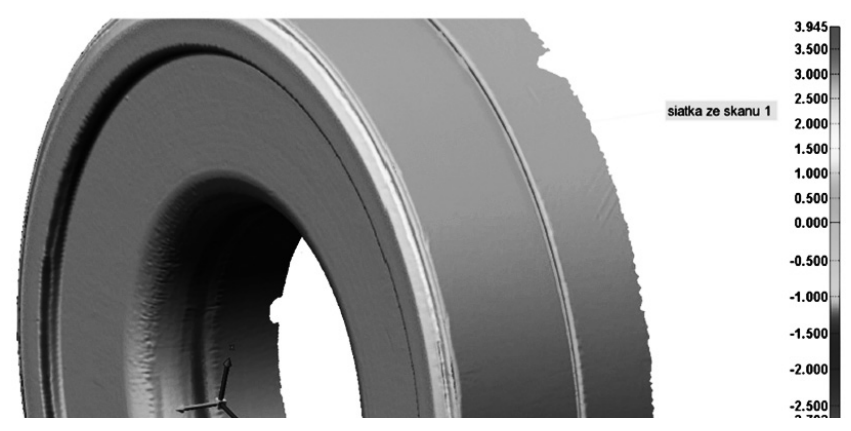

Rys. 5. Porównanie zeskanowanych obrazów matrycy z modelem CAD po odkuciu 10000 szt.

Fig. 5. Comparison of scanned matrix images with CAD model after 10000 pieces

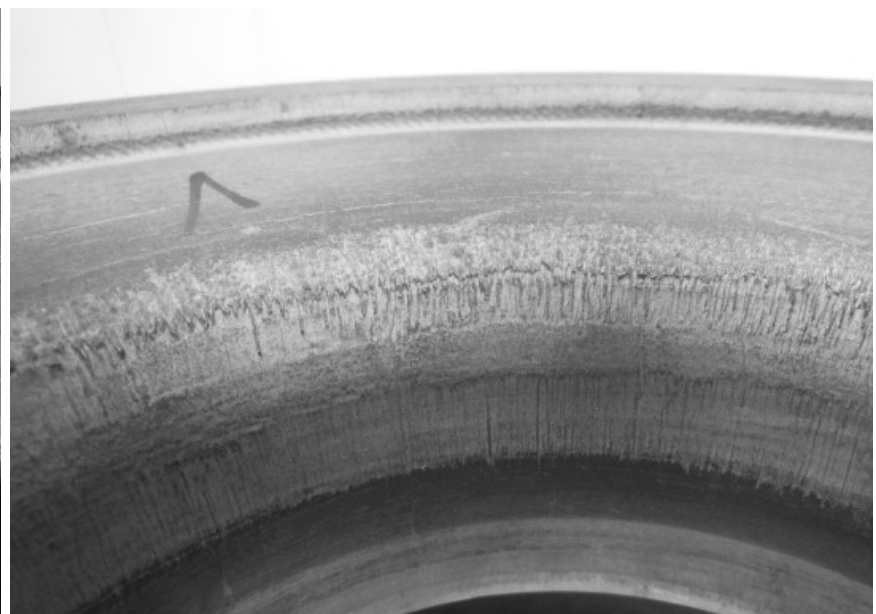

Rys. 3. Widok makro powierzchni roboczej analizowanej matrycy po odkuciu 10000 odkuwek

Fig. 3. Macro view of the working surface of the analyzed matrix after the forging of 10000 forgings 
Pomiary mikrotwardości HV0,1

Pomiar mikrotwardości wykonano dla analizowanej matrycy w miejscach $(1 \div 6)$ zaznaczonych na rysunku 6 na odcinku $10 \mathrm{~mm}$ od powierzchni roboczej w głąb narzędzi. Pomiar wykonano na tak dużej głębokości w celu analizy zmian twardości w strefie wpływu ciepła.

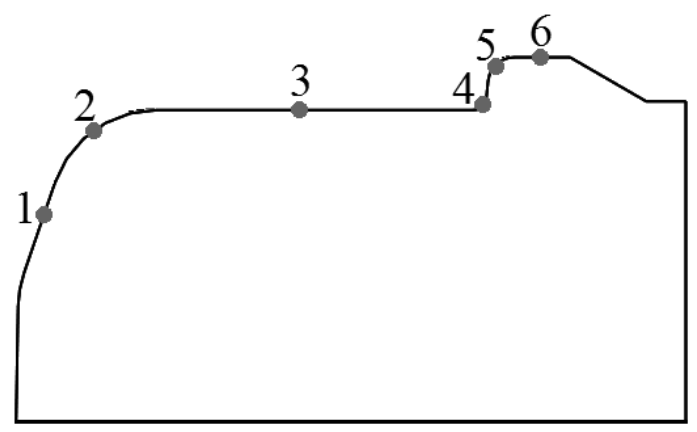

Rys. 6. Przekrój matrycy z zaznaczonymi miejscami w których wykonano pomiar mikrotwardości

Fig. 6. Cross section of the matrix with the places where microhardness was measured

Punkt 1

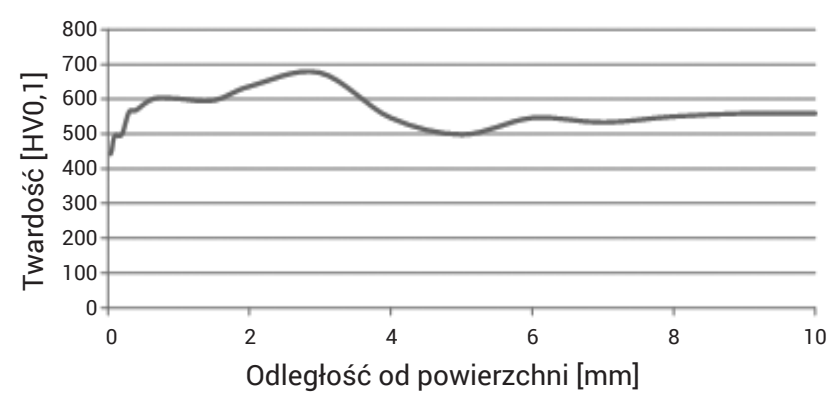

Punkt 3

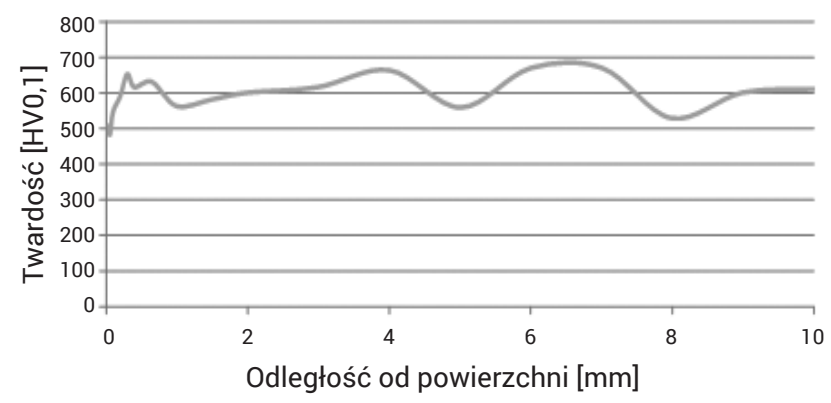

Punkt 5

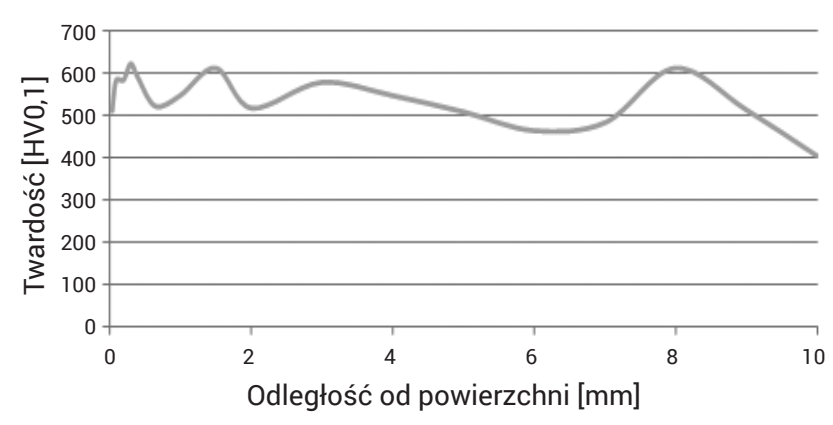

Na wyznaczonych profilach mikrotwardości można zauważyć, że niezależnie od miejsca pomiaru, w warstwie przypowierzchniowej występuje spadek twardości nawet do ok. $450 \mathrm{HV0}, 1$. W obszarach położonych głębiej następuje stopniowy wzrost twardości HV0,1 do twardości rdzenia. Największy spadek twardości występuje na promieniu w punkcie 2, w tym miejscu obserwowano również największe zużycie analizowanej matrycy. Dodatkowo w odległo-

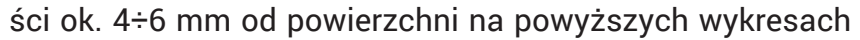
można zaobserwować zmianę profilu twardości.

\section{Badania metalograficzne}

Badania metalograficzne przeprowadzono na tych samych próbkach, dla których wykonane zostały pomiary rozkładu mikrotwardości. W celu ujawnienia struktury materiału próbki zostały wytrawione $3,5 \%$ nitalem. Na rysunku 8 przedstawiono mikrostrukturę $\mathrm{w}$ strefie przetopienia oraz $\mathrm{w}$ rdzeniu analizowanej matrycy. W obszarze strefy przetopienia i w strefie wpływu ciepła zaobserwować można bardzo rozległe zmiany mikrostruktury (rys. 8a).

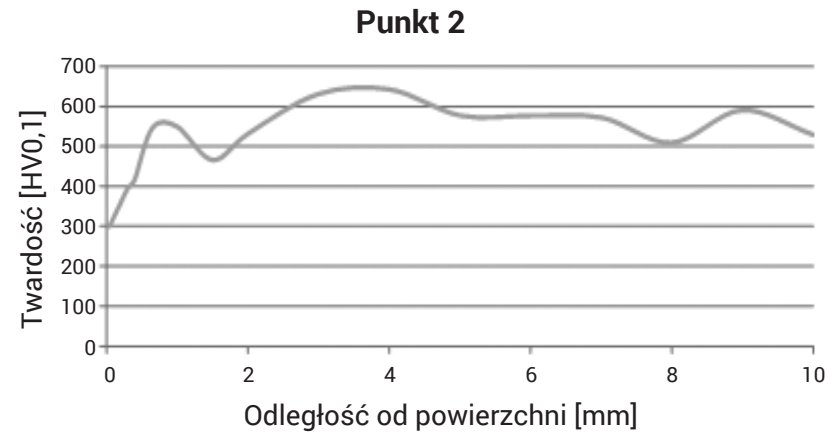

Punkt 4

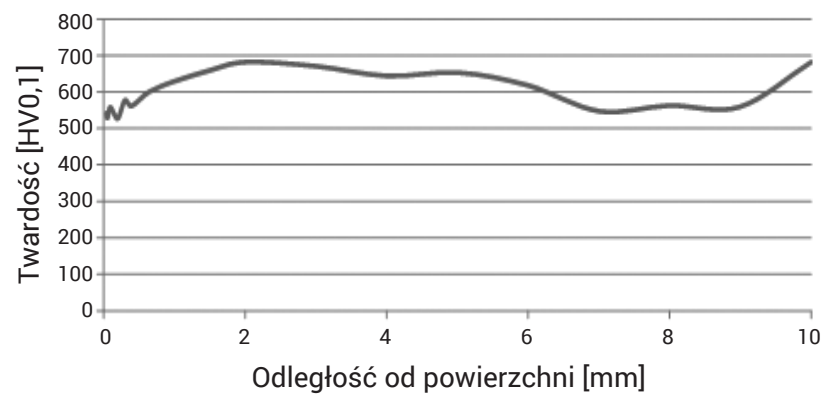

Punkt 6

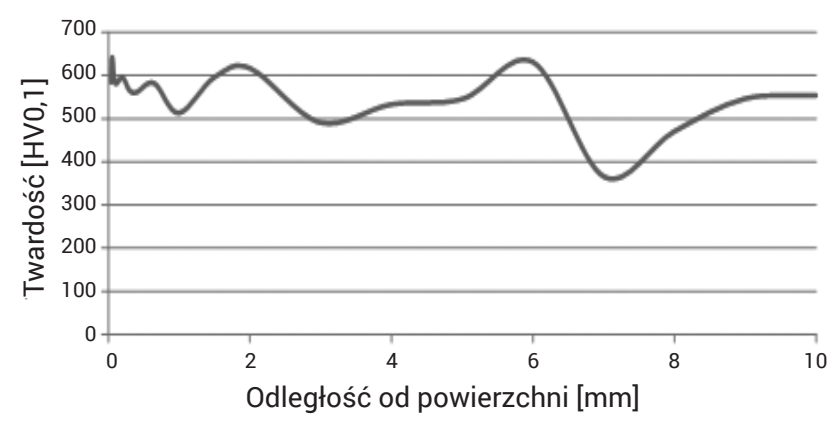

Rys. 7. Profile mikrotwardości HV0,1 na przekroju analizowanej matrycy

Fig. 7. Microhardness profiles $\mathrm{HVO}, 1$ on the section of the analyzed matrix 

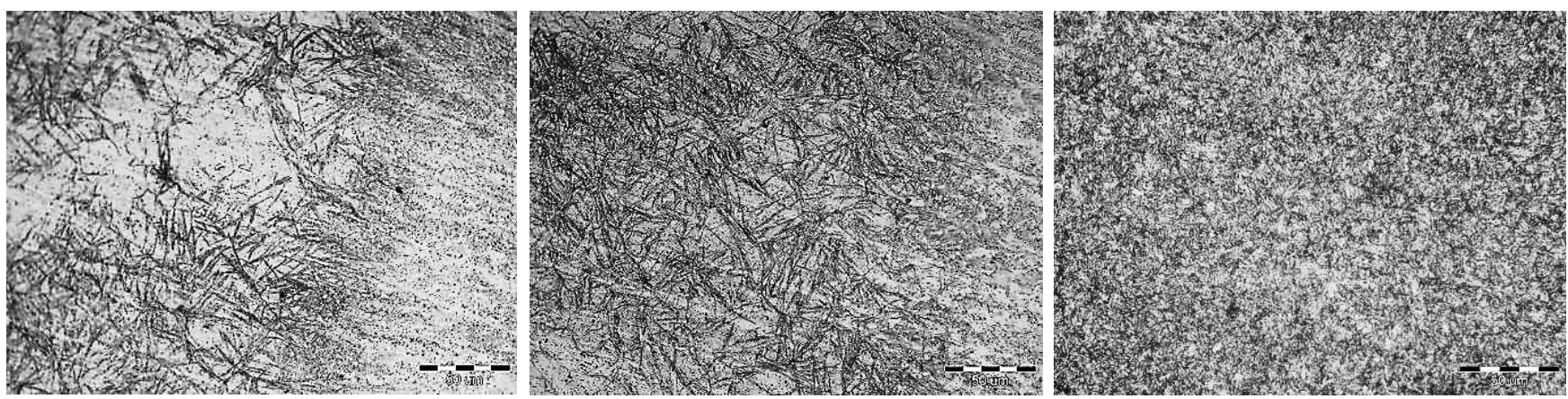

Rys. 8. Mikrostruktura napawanej matrycy: a) w strefie przetopienia, b) w strefie wpływu ciepła, c) w rdzeniu matryc

Fig. 8. Microstructure of the welded matrix: a) in the melting zone, b) in the heat affected zone, c) in the core of the matrix

\section{Opis zmian zachodzących w warstwie wierzchniej}

Szczegółowej analizy zmian w warstwie wierzchniej w wybranych obszarach dokonano przy użyciu mikroskopu skaningowego TESCAN VEGA 3. Wyniki obserwacji analizy warstwy wierzchniej przedstawiono na rysunku 9.

W obszarze promienia w środkowej części matrycy na powierzchni widoczne są bruzdy charakterystyczne dla zużycia ściernego (rys. 9a), co potwierdzają różnie wyniki analizy wymiarowej przy użyciu skanera laserowego. Na przekroju widoczne są również pęknięcia przebiegające prostopadle od powierzchni, co świadczy o braku odkształceń plastycznych warstwy wierzchniej w tym obszarze. Na płaskiej części analizowanej matrycy widoczne jest duże pęknięcie (rys. 9b), widoczne również przy makroanalizie, przebiegające w kierunku obwodowym. W obszarze mostka matrycy gdzie na skanie widoczne jest zużycie, występują bruzdy typowe dla zużycia ściernego. Ponadto na całej powierzchni roboczej napawanej matrycy nie zaobserwowano siatki pęknięć cieplno-mechanicznych oraz stwierdzono większą odporność na utlenianie niż w przypadku analizowanych wcześniej narzędzi tego typu po azotowaniu.
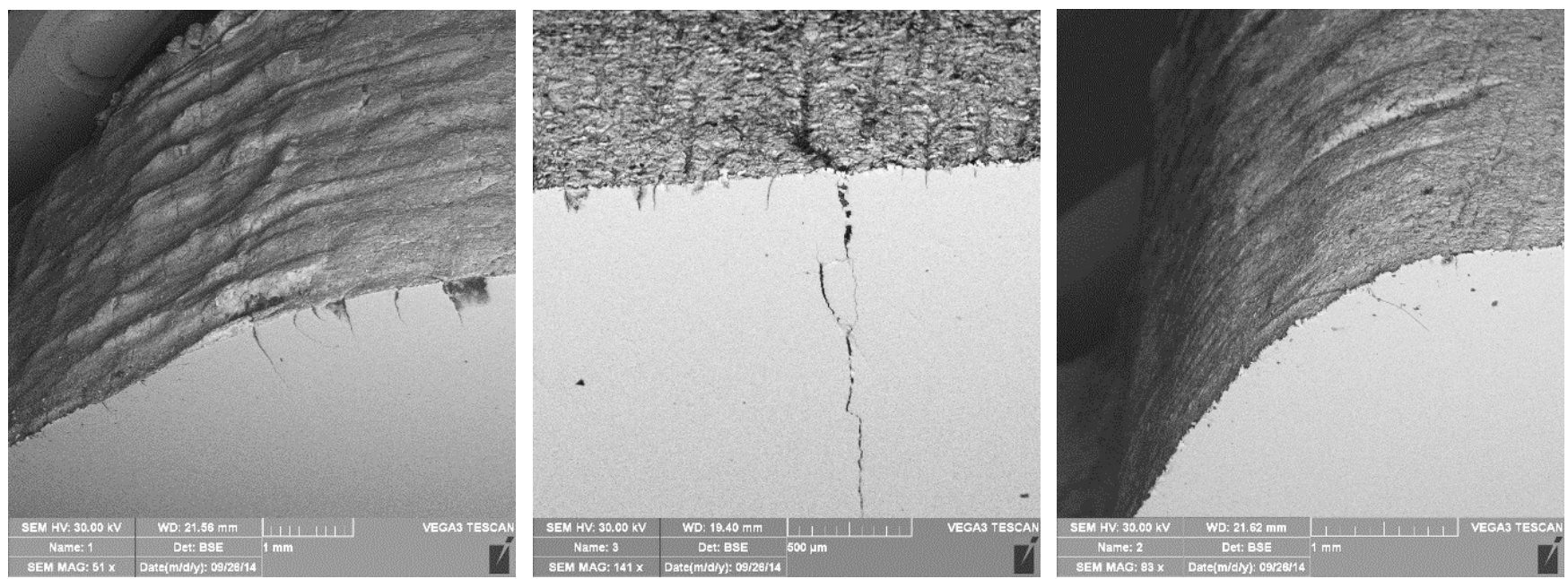

Rys. 9. Powierzchnia robocza matrycy w obszarze: a) promienia w środkowej części, b) płaskiej części, c) mostka matrycy Fig. 9. Working surface of the matrix in the area: a) radius in the middle part, b) flat part, c) matrix bridge

\section{Wnioski}

Na podstawie przeprowadzonej analizy dolnej matrycy stosowanej w drugiej operacji kucia (kucie wstępne) odkuwki kołnierza z szyjką, która była dwukrotnie regenerowana przez napawanie, stwierdzono, że metoda ta pozwala na skuteczne regenerowanie narzędzi kuźniczych. Pozwala to na kilkukrotne wykorzystanie tego samego narzędzia, którego wykonanie jest kilkukrotnie droższe od jego regeneracji przez napawanie. Ponadto stwierdzono zdecydowanie mniejsze zużycie matrycy po napawaniu w porównaniu z matrycami azotowanymi po odkuciu podobnej liczby odkuwek.

W celu dalszej analizy możliwości regeneracji narzędzi kuźniczych przez napawania wytypowano inne narzędzie stosowane w tym procesie, mianowicie wypełniacz wkładki, który również cechuje się stosunkowo niską trwałością. Została przeprowadzona wstępna analiza zużycia oraz zakwalifikowanie tego narzędzia do regeneracji przez napawania. Wybrano również nowe materiały do napawania takie jak: Celsit 21, Celsit V, Celsit F, Celsit N, które w najbliższym czasie będą testowane. 


\section{Literatura}

[1] Altan T.: Cold and hot forging fundamentals and application, ASM Internation, Ohio, 2005.

[2] Anders P, Hogmark S, Bergström J.: Simulation and evaluation of thermal fatigue cracking of hot work tool steels, International Journal of Fatigue 2004 (10), pp. 1095-1107.

[3] Archard J.F.: Contact and rubbing of flat surfaces, Journal of Applied Physics, 24, pp. 981-988,1953

[4] Asm metals handbook volume 14, Forming and forging, pp. 337-338.

[5] Bariani P. F., Dal Negro T., Fioretti M.: Joint use of physical and numerical simulation techniques in predicting process parameters evolution and microstructure in forging Nimonic $80 \mathrm{~A}$ turbine blades, Proceedings of the 2nd Esaform, Guimares, Portugal, 1999.

[6] Barrau O., Boher C., Vergne C., Rezai-Aria F.: Investigation of Friction and Wear Mechanism of Hot Forging Tool Steels, 6th Int. Tooling Conference, Karlstadt 2002.
[7] Barron R.F.: How cryogenic treatment controls wear, 21 st Inter-Plant Tool and Gage Conference. Shreveport, LA, USA,1982. (wg ASM Handbook, t.4, pp. 205

[8] Barylski A., Deja M.: Surface flatness control in singl plate lapping [online], [dostęp 10 maj 2013] Dostępny w internecie: < http://home.mit.bme. hu/ kollar/IMEKO-procfiles-for-web/congresses/WC-16th-Wien-2000/ Papers/Topic\%2002/Barylski.PDF>

[9] Basqiun O.H.: The exponential law in endurance tests, Am. Soc. Test. Maer. Proc., 10; pp. 625-630.

[10] Baumel A., Seeger T.: Material Data for Cyclic Loading, Suplement 1, Marterials Science Monographs, 61, Elsevier Science Publishers, Amsterdam 1990. 